\title{
Elektrische Status Epilepticus in Slaap
}

Op 15 oktober 2020 promoveerde Bart van den Munckhof aan de Universiteit Utrecht op het proefschrift getiteld Electrical Status Epilepticus in Sleep ${ }^{\mathrm{I}}$. Van den Munckhof toont aan dat inflammatie en vroeg ontstane schade aan de thalamus een belangrijke rol spelen bij het ontstaan van elektrische status epilepticus in slaap (ESES). Overige bevindingen zijn dat verstoring van de herstelfunctie van slaap een relatie heeft met gedragsproblemen en dat behandeling met corticosteroïden vermoedelijk het meest effectief is.

Epilepsie met elektrische status epilepticus in slaap (ESES) is een epilepsiesyndroom bij kinderen dat wordt gekenmerkt door vrijwel continue epileptische activiteit in slaap en door leer- en gedragsproblemen. Elektrische status epilepticus in slaap werd voor het eerst beschreven in I97I bij zes kinderen bij wie in non-REM slaap voortdurende multifocale of gegeneraliseerde epileptische activiteit, met een zogenoemde piekgolfindex van $85 \%$ (percentage van de slaap waarin epileptische activiteit wordt geregistreerd) werd gevonden (Patry et al., I97I). In meer recente literatuur wordt als definitie voor het ESES syndroom een piekgolfindex van 50-85\% met stagnatie of regressie van ontwikkeling gehanteerd (Scheltens-De Boer, 2009). Een groot deel van de kinderen met het ESES syndroom heeft ook af en toe een klinische epileptische aanval, maar de epileptische activiteit in slaap is meestal subklinisch. Hoewel het typische EEG patroon verdwijnt in de puberteit zijn de ontwikkelingsproblemen vaak blijvend.

Het doel van het promotieonderzoek van Van den Munckhof was om I) handvatten te bieden voor de vroegtijdige herkenning van kinderen met een verhoogd risico op het ontwikkelen van ESES, 2) meer inzicht te krijgen in de oorzaken van ESES en hoe ESES leidt tot leer- en gedragsproblemen, en 3) te onderzoeken wat de beste behandeling is voor kinderen met het ESES syndroom.

\section{Wat zijn de risicofactoren?}

Van den Munckhof bestudeerde een cohort van 30 kinderen die rond de geboorte een beschadiging opliepen van de thalamus. Deze kinderen werden vanaf de leeftijd van twee jaar gevolgd met slaap-EEG's en neuropsychologische onderzoek. Ook werden de MRI-scans, die gemaakt waren op de leeftijd van drie maanden, bestudeerd. Het thalamus- en het hersenvolume werd gemeten en diffusiekarakteristieken van de thalamus werden in kaart gebracht. Van den Munckhof vond dat bijna alle kinderen met zowel uni- als bilaterale thalamusschade op de kinderleeftijd ESES kregen. Lateralisatie van thalamusletsel was niet gerelateerd aan lateralisatie van epileptiforme activiteit. Het resterende thalamusvolume, gemeten op de MRI op de leeftijd van drie maanden, bleek de belangrijkste voorspeller van de ontwikkeling op lange termijn (van den Munckhof et al., 20I9).

Bij een derde tot de helft van de kinderen met het ESES syndroom wordt een structurele afwijking van de hersenen gevonden, bijvoorbeeld een aanlegstoornis van de hersenschors of een beschadiging die rond de geboorte is ontstaan. Soms wordt een genetische oorzaak gevonden, zoals een GRIN2A mutatie. Bij ongeveer de helft van de kinderen met het ESES syndroom wordt geen oorzaak gevonden. Er zijn aanwijzingen dat inflammatie een belangrijke rol speelt bij epilepsie met ESES. De activatie van het immuunsysteem kan in kaart gebracht worden door het meten van ontstekingseiwitten, zogenoemde cytokines en chemokines, en auto-antistoffen. Van den Munckhof verrichtte een systematische literatuurstudie en meta-analyse van studies naar ontstekingseiwitten bij mensen met epilepsie en vond dat verschillende ontstekingseiwitten met een brede functie (zoals interleukine 6, IL-6) verhoogd zijn bij mensen met epilepsie en dat bij verschillende vormen van epilepsie bepaalde patronen in de activatie van deze eiwitten te onderscheiden zijn (de Vries et al., 2016). Bovendien verschilden de waarden van ontstekingseiwitten, gemeten in bloed, bij kinderen met het ESES syndroom, van gezonde controles. De hoeveel-

${ }^{1}$ Promotor: Professor K.P.J. Braun, kinderneuroloog UMC Utrecht, Co-promotor: Dr. F.E. Jansen, kinderneuroloog UMC Utrecht 
heid ontstekingseiwit IL- 6 daalde significant na behandeling met ontstekingsremmers. Dit ging samen met een afname van de piekgolfindex gemeten in het EEG tijdens slaap en met een verbetering van de neuropsychologische testresultaten (van den Munckhof et al., 20I6). Deze bevinding suggereert een belangrijke plaats voor ontstekingsremmers bij de behandeling van het ESES syndroom.

Relatie tussen slaap- en ontwilkkelingsproblemen Een mogelijke verklaring voor de ontwikkelingsproblemen bij kinderen met het ESES syndroom wordt gezocht in de "synaptische homeostase hypothese". Deze hypothese beschrijft dat er bij het wakker zijn nieuwe synapsen worden gevormd en dat synapsen worden versterkt ("synaptische vermeerdering"). In slaap wordt een deel van de synapsen opgeheven en neemt de sterkte van andere synapsen af ("synaptische vermindering”). Door deze synaptische vermindering blijft het hersennetwerk compact en efficiënt en is er na een nacht slaap weer ruimte om nieuwe ervaringen en informatie te onthouden. De synaptische homeostase is in het EEG te herkennen aan de deltagolven (trage hersengolven), een kenmerk van diepe slaap. Van den Munckhof vond dat kinderen met het ESES syndroom met gedragsproblemen een ernstigere verstoring van de synaptische vermindering in slaap hadden dan kinderen met ESES syndroom zonder gedragsproblemen (van den Munckhof et al., 2020)

\section{Effectieve behandeling?}

In een meta-analyse van de literatuur en een studie in Wilhelmina Kinderziekenhuis vond van den Munckhof dat routine anti-epileptica vaak niet effectief zijn bij de behandeling van ESES, terwijl benzodiazepines (zoals clobazam) en behandeling met corticosteroïden effectiever zijn (van den Munckhof et al., 2015; 2018). Bij kinderen met unilaterale structurele hersenafwijkingen was chirurgische behandeling het meest effectief. Vanwege de veelal retrospectieve en kleine studies die in de meta- analyse werden meegenomen, biedt de analyse geen definitief bewijs welke behandeling de beste is, maar slechts aanwijzingen. Een multicentrum gerandomiseerde klinische medicatie trial, waarin behandeling met clobazam en behandeling met corticosteroïden wordt vergeleken (acroniem: RESCUE ESES) startte in 20I4. Tijdens zijn promotietraject heeft Van den Munckhof deze trial zeer kundig gecoördineerd en het studie protocol gepubliceerd (van den Munckhof et al., 2020).

Conclusie en implicatie

Van den Munckhof heeft in zijn proefschrift diverse aspecten van het ESES syndroom onderzocht en nieuwe inzichten verworven in de onderliggende pathofysiologie, etiologie en behandeling van dit epilepsiesyndroom. De resultaten van dit proefschrift dragen in belangrijk mate bij aan vroege herkenning en een betere behandeling met uiteindelijk een betere toekomst voor kinderen die gediagnosticeerd worden met dit ernstige epilepsie syndroom.

\section{Referenties}

de Vries EE, van den Munckhof B, Braun KP, et al. (2016) Inflammatory mediators in human epilepsy: A systematic review and meta-analysis. Neurosci \& Biobehav Rev 63:177-90.

Patry G, Lyagoubi S, Tassinari CA. (I97I) Subclinical "electrical status epilepticus" induced by sleep in children. Arch Neurol 24(3):242-252. D

Scheltens-De Boer M. (2009) Guidelines for EEG in encephalopathy related to ESES/CSWS in children. Epilepsia 50:13-17

van den Munckhof B, Zwart AF, Weeke LC, et al. (2020) Perinatal thalamic injury: MRI predictors of electrical status epilepticus in sleep and long-term neurodevelopment. NeuroImage: Clinical 26:102227.

van den Munckhof B, de Vries EE, Braun KP, et al. (20I6) Serum inflammatory mediators correlate with disease activity in electrical status epilepticus in sleep (ESES) syndrome. Epilepsia 57(2):e45-50.

van den Munckhof B, Gefferie SR, van Noort SAM, et al. (2020) Sleep slow wave homeostasis and cognitive functioning in children with electrical status epilepticus in sleep. Sleep 43(11)

van den Munckhof B, van Dee V, Sagi L, et al. (2015) Treatment of electrical status epilepticus in sleep: A pooled analysis of 575 cases. Epilepsia 56(11):1738-46. van den Munckhof B, Alderweireld C, Davelaar S, et al. (2018) Treatment of electrical status epilepticus in sleep: Clinical and EEG characteristics and response to I47 treatments in 47 patients. Eur J of Paediatr Neurol 22(1):64-71

van den Munckhof B, Arzimanoglou A, Perucca E, et al. (2020) Corticosteroids versus clobazam in epileptic encephalopathy with ESES: a European multicenter randomized controlled clinical trial (RESCUE ESES). Trials 21(1):957. 